University of Nebraska - Lincoln

DigitalCommons@University of Nebraska - Lincoln

Use of a Simulation Model to Evaluate the Influence of Reproductive Performance and Management Decisions on Net Income in Beef Production

\author{
L. A. Werth \\ University of Nebraska-Lincoln \\ S. M. Azzam \\ University of Nebraska-Lincoln \\ Merlyn K. Nielsen \\ University of Nebraska-Lincoln, mnielsen1@unl.edu \\ J. E. Kinder \\ University of Nebraska-Lincoln, kinder.15@osu.edu
}

Follow this and additional works at: https://digitalcommons.unl.edu/animalscifacpub

Part of the Animal Sciences Commons

Werth, L. A.; Azzam, S. M.; Nielsen, Merlyn K.; and Kinder, J. E., "Use of a Simulation Model to Evaluate the Influence of Reproductive Performance and Management Decisions on Net Income in Beef Production" (1991). Faculty Papers and Publications in Animal Science. 485.

https://digitalcommons.unl.edu/animalscifacpub/485

This Article is brought to you for free and open access by the Animal Science Department at DigitalCommons@University of Nebraska - Lincoln. It has been accepted for inclusion in Faculty Papers and Publications in Animal Science by an authorized administrator of DigitalCommons@University of Nebraska - Lincoln. 


\title{
USE OF A SIMULATION MODEL TO EVALUATE THE INFLUENCE OF REPRODUCTIVE PERFORMANCE AND MANAGEMENT DECISIONS ON NET INCOME IN BEEF PRODUCTION1,2
}

\author{
L. A. Werth, S. M. Azzam, M. K. Nielsen and J. E. Kinder ${ }^{3}$ \\ University of Nebraska ${ }^{4}$, Lincoln 68583-0908
}

\begin{abstract}
A stochastic dynamic model of reproduction and a deterministic cow-herd economic simulation model were used to evaluate how management decisions and reproductive performance interact to influence net income in a cow-calf operation $(1,000$ cows) for $1 \mathrm{yr}$ of production. The stochastic model was used to determine herd performance when length of breeding season $(45,70$, or $120 \mathrm{~d})$ interacted with three postpartum intervals of anestrus (48, 65 , or $90 \mathrm{~d}$ ) and three conception rates at first service $(60,70$, or $80 \%$ ). Short, moderate, and long postpartum intervals were used to reflect differences in reproductive performance. In addition, replacement heifers were bred beginning either 3 wk ahead of the cow herd or at the same time as the cow herd. Fifty-four simulations were generated. Inputs into the economic model were herd performance, livestock and feed prices, nonfeed costs, and feed requirements for 1 yr of production. Feed requirements were calculated separately for each postpartum interval to reflect three different body condition scores, thin, moderate, and good, to correspond with long, moderate, and short postpartum intervals. Net income was greatest with $70-\mathrm{d}$ breeding seasons when the postpartum interval was short or moderate. When the postpartum interval was long, net income was greatest with 120- $\mathrm{d}$ breeding seasons because pregnancy rates, as a result of the long breeding season, were highest and feed costs were lowest for thin cows. Overall, net income was greatest when cows were managed to have postpartum intervals of moderate length. Breeding heifers 3 wk before the cows provided the most economic benefit with long postpartum intervals.

Key Words: Beef Production, Reproductive Efficiency, Economics, Computer Simulation
\end{abstract}

J. Anim. Sci. 1991. 69:4710-4721

Introduction

Short breeding seasons have been advocated

\footnotetext{
${ }^{1}$ Published as paper No. 9536, Journal Ser., Nebraska Agric. Res. Div. This research was supported by USDA CSRS Special Grant 88-34154-3802.

${ }^{2}$ We thank Tom Jenkins, Cal Ferrell, and George Pfeiffer for their valuable input to this project and Marshall Frasier for gathering and updating price information.

${ }^{3}$ Reprint requests: James E. Kinder, A224j Animal Science, University of Nebraska, Lincoln 68583-0908.

${ }^{4}$ Dept. of Anim. Sci.

Received March 8, 1991

Accepted June 28, 1991.
}

to improve the efficiency of the cow herd because a more uniform calf crop is produced at weaning (Dzuik and Bellows, 1983; Short et al., 1990). However, for short breeding seasons to be most effective, a high percentage of cows must be capable of conceiving early during the breeding season. Cows that give birth late during the season and(or) have extended postpartum intervals of anestrus (duration between calving and first postpartum estrus) may not become pregnant before the end of a 45-d breeding season. Long breeding seasons result in higher overall pregnancy rates; however, more cows will repeatedly calve late, resulting in younger, and thus lighter, calves if all calves are weaned on the same date. 
Bellows et al. (1979) reported that the highest incidence of calf loss in the beef industry was due to the inability of the cow to become pregnant by the end of the breeding season. In many situations, the duration of postpartum anestrus dictates whether a cow will conceive during the breeding season. Cows in moderate to good body condition before calving have a higher probability of expressing estrus before or early during the breeding season (Momont and Pruitt, 1989). However, the additional feed required to maintain cows in good body condition may outweigh any increase in biological output.

There is a paucity of research that has evaluated the costs and returns of various management practices to a cow-calf operation. Therefore, two computer simulation models were used to evaluate how short, moderate, and long postpartum intervals interact with management practices to influence net income of a cow-calf operation. A stochastic model was used to simulate the reproductive performance of the cow herd (Azzam et al., 1990). Outputs from the stochastic model were used as inputs into an economic model that calculated the net income of the operation for $1 \mathrm{yr}$ of production.

\section{Materials and Methods}

Inputs into the economic model, written in LOTUS 1-2-3, were herd performance, feed requirements, and prices. The model was used to calculate a net income for $1 \mathrm{yr}$ of production using the resources and prices commonly found on a cow-calf operation located in the Sandhills region of Nebraska. The inputs can be changed to reflect a beef operation in any location.

Herd Performance. The biological inputs for the economic model were the outputs from a stochastic dynamic model developed to describe reproductive processes in beef cattle (Azzam et al., 1990, 1991). Parameters of the stochastic model were based on values gleaned from the literature and analysis of large data sets to characterize the distribution of occurrence of certain reproductive processes. Reproductive traits of a simulated cow herd were generated based on distribution functions, means, and variances of traits that do not have a direct economic value. In this study, the cow herd was defined as one having the genetic potential for mature body size of $455 \mathrm{~kg}$, which is similar to many crossbred Hereford $x$ Angus cow herds in the Nebraska Sandhills, and a moderate level of milk production $(-5.0$ $\mathrm{kg} / \mathrm{d}$ ).

The mean postpartum interval $(48,65$, or 90 d) and conception rate at first service $(60,70$, or $80 \%$ ) were varied to simulate differences in reproductive performance that may result from different management practices. The probability of conception at first service was similar for each postpartum interval and level of body condition. The different combinations of reproductive performance were simulated to determine how length of breeding season $(45,70$ or 120 d) interacts with postpartum intervals and conception rates at first service to determine net income. In addition, the breeding season for replacement heifers was initiated either 3 wk ahead of the breeding season of the cow herd or at the same time as the breeding season of the cow herd and continued until the end of the breeding season for the mature cows. Fiftyfour simulations were generated from all possible combinations of these management decisions and levels of reproductive performance. The stochastic model was replicated a given number of times with a constant number of females ( $n=1,000$ females) until the herd "stabilized" for each combination of inputs.

Herd performance included the number of mature cows, 2-yr-old cows, and replacement heifers removed from the herd during the year because they were not pregnant when calves were weaned, had physical problems, or died. All cows that were not pregnant at weaning were culled. The economic model calculated the replacement rate, which was defined as the number of heifer calves retained at weaning and purchased, if necessary, to maintain the cow herd at a constant size.

Weaning data were generated in the stochastic model and entered as the average weight and number of calves in each of three weight ranges. Steer and heifer calves were classified by weight because the price per kilogram of calf varied according to weight and sex. The light weight range included steer and heifer calves weighing $<182 \mathrm{~kg}$ and $<170$ $\mathrm{kg}$, respectively. The medium weight range included steer and heifer calves weighing 183 to $205 \mathrm{~kg}$ and 171 to $193 \mathrm{~kg}$, respectively. The heavy weight range included steer and heifer calves weighing $>206 \mathrm{~kg}$ and $>194 \mathrm{~kg}$, respectively.

Feed Requirements. Feed requirements were calculated to simulate the expected performance of the cow herd. Feed requirements were 
TABLE 1. INFLATION-ADJUSTED PRICES FOR LIVESTOCK AND FEED BASED ON AVERAGE OF 10-YEAR PERIOD (1980 TO 1989) FOR A SPRING-CALVING COW HERD LOCATED IN A RANGE AREA

\begin{tabular}{|c|c|c|}
\hline Item & Unit & Price \\
\hline \multicolumn{3}{|l|}{ Livestock } \\
\hline Steer calves: 136 to $182 \mathrm{~kg}^{2}$ & $\$ / \mathbf{k g}$ & 2.17 \\
\hline Steer calves: 183 to $227 \mathrm{~kg}^{\mathrm{a}}$ & $\$ / \mathbf{k g}$ & 2.05 \\
\hline Steer calves: 228 to $273 \mathrm{~kg}^{\mathrm{a}}$ & $\$ / \mathbf{k g}$ & 1.93 \\
\hline Heifer calves: 136 to $182 \mathrm{~kg}^{\mathrm{a}}$ & $\$ / \mathrm{kg}$ & 1.89 \\
\hline Heifer calves: 183 to $227 \mathrm{~kg}^{\mathrm{a}}$ & $\$ / \mathrm{kg}$ & 1.82 \\
\hline Heifer calves: 228 to $273 \mathrm{~kg}^{\mathrm{a}}$ & \$/kg & 1.74 \\
\hline Cull heifers: 318 to $364 \mathrm{~kg}$ & $\$ / \mathrm{kg}$ & 1.64 \\
\hline Cull 2-yr-old cows b & $\$ / \mathrm{kg}$ & 1.39 \\
\hline Cull utility cows $\mathrm{s}^{\mathrm{a}}$ & $\$ / \mathbf{k g}$ & 1.05 \\
\hline Cull pregnant cows ${ }^{\mathrm{c}}$ & $\$ /$ cow & 664 \\
\hline Cull bulls ${ }^{\mathrm{a}}$ & $\$ / \mathrm{kg}$ & 1.33 \\
\hline Replacement bulls ${ }^{\mathrm{d}}$ & \$/bull & 1,984 \\
\hline \multicolumn{3}{|l|}{ Feed } \\
\hline Summer pasture ${ }^{e}$ & \$IAUM ${ }^{f}$ & 15.81 \\
\hline Winter pasture & S/AUM & 7.91 \\
\hline Prairie hay ${ }^{\mathrm{h}}$ & $\$ / 100 \mathbf{~ k g}$ & 6.44 \\
\hline Corn & $\$ / 100 \mathrm{~kg}$ & 11.55 \\
\hline Protein supplement $t^{j}$ & $\$ / 100 \mathrm{~kg}$ & 32.44 \\
\hline $32 \%$ Range cubo $j$ & $\$ / 100 \mathrm{~kg}$ & 29.27 \\
\hline Salt and mineralk & $\$ /$ cow & 4.02 \\
\hline
\end{tabular}

${ }^{a}$ USDA Agric. Marketing Service, Torrington, WY.

${ }_{80 \%}$ of price paid for 228 to $273 \mathrm{~kg}$ heifer calves as reported by USDA Agric Marketing Service (Fiske, 1987).

${ }^{c}$ Cattle Fax, Denver CO.

dAmerican Angus Assoc., St. Joseph, MO; American Hereford Assoc., Kansas City, MO.

'Personal communication. Nebraska Farm Real Estate Market Developments (1988 to 1989).

A Animal unit month.

BPersonal communication. J. Robb. Ext. Farm Management Specialist. Panhandle Res. and Ext. Center, Scottsbluff, NE.

h Cornhusker Economics (1980 to 1989).

iWellman and Lutgen (1990).

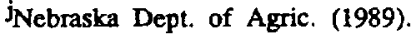

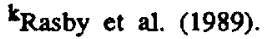

calculated on a 12-mo basis beginning at weaning on October 15 . The feeds and forage represent those commonly found on cow-calf operations located in the Sandhills area of Nebraska. In all scenarios, it was assumed that cows grazed summer pastures between June 1 and October 31 and winter pastures between November 1 and December 31 .

Diets for growing replacement heifers were balanced to meet energy requirements for maintenance $\left(\mathrm{NE}_{\mathbf{m}}\right)$ as determined by the equation $\mathrm{NE}_{\mathrm{m}}(\mathrm{Mcal})=.077 \cdot \mathrm{BW}_{\mathbf{k g}}{ }^{.75}$. Crude protein and additional energy required for growth were based on recommendations by the NRC (1984). Diets for bred heifers, 3-yr-old cows, mature cows, and bulls were balanced to meet requirements for energy and protein according to live $\mathrm{BW}$ as recommended by the NRC (1984). The timing of changes in the feeding regimen corresponded to actual management practices in ranch operations.

The amounts of feed for bred heifers, 3-yr-old cows, and mature cows were calculated separately for simulations with different durations of postpartum anestrus to reflect three different body condition scores. The level of feeding was simulated to maintain cows in body condition scores (BCS) of 3,5, or 7 on a 9-point scale throughout the year. Mature cows in moderate body condition (BCS $=5$ ) were assumed to have a BW of $477 \mathrm{~kg}$ at midgestation and, on the average, would express a postpartum interval of anestrus of $65 \mathrm{~d}$ (Zalesky et al., 1984). Mature cows, similar in frame size, in thin body condition $(\mathrm{BCS}=3$ ) were assumed to have a BW of $423 \mathrm{~kg}$ at midgestation and, on the average, would express a postpartum interval of anestrus $>65 \mathrm{~d}$. Thin cows were assumed to exhibit postpartum intervals of anestrus of $90 \mathrm{~d}$ as a herd average, which is in agreement with research reported by Houghton et al. (1990). Likewise, cows weighing $477 \mathrm{~kg}$ in moderate body condition were assumed to weigh $532 \mathrm{~kg}$ in good condition (fleshy with considerable fat: $\mathrm{BCS}=$ 7) and would be expected to express a postpartum interval of anestrus $<65 \mathrm{~d}$. A postpartum interval of anestrus of $48 \mathrm{~d}$ was used because it corresponds to the lowest possible mean date of first estrus if using the distribution function developed by Azzam et al. (1991) and assuming that cows were not exposed to bulls postpartum. These changes in $\mathrm{BW}$ and BCS are based on the assumption that a one-unit change in BCS is equivalent to a change of $27.3 \mathrm{~kg}$ in BW (C. L. Ferrell, personal communication).

Prices. All prices were collected from a variety of sources over a 10-yr period (1980 to 1989) when available and adjusted for inflation to 1989 dollars using an implicit price deflator for gross national product (Business Conditions Digest, 1989). The 10-yr average price was used to reduce the annual fluctuation in agricultural prices. All calves and cull animals were assumed to be sold in October and November after weaning; therefore, prices reflect the time of year livestock were sold 
(Table 1). Because feedstuffs are often purchased at different times of the year rather than during one season, the average market price for the year for each feedstuff was used (Table 1).

Non-feed costs were categorized as cash, fixed, and other (Table 2). Cash costs included veterinary, marketing, machinery-equipment (including repairs), and miscellaneous costs. Fixed costs included the costs of building and equipment (including interest and depreciation) and death loss. Other costs included labor, overhead, and operator management costs. Details on how prices were determined have been previously described (Werth et al., 1991).

Operation of the Model. The size of the cow herd was set at 1,000 . The breeding season for all cows began May 20 and continued for 45,70 , or $120 \mathrm{~d}$ depending on the management decision. All calves were weaned on October 15 . In management systems in which the breeding season for heifers was initiated 3 wk before that for the cows, the breeding season for heifers began April 29 and ended concurrently with that for the mature cows; therefore, heifers were exposed to bulls for an additional 21 d. All breeding was by natural service with one bull per 25 cows. One-fourth of the bulls were replaced each year.

A summer and winter herd inventory was generated for each simulation according to the herd performance used as inputs. The summer and winter inventories provide a summary of the number of animals bought or born and sold or lost for each simulation between June 1 and October 31 and between November 1 and May 31. The inventories were used to calculate total herd costs including total feed consumed, total feed costs, and non-feed costs. All calves were sold at weaning except for heifer calves retained for replacement purposes. Criteria used for selecting replacement heifer calves by weight class were described previously (Werth et al., 1991).

The following equation was used to calculate net income: Net income $=$ Livestock sales - Replacement livestock purchases - Total yearly feed costs - Total other cash costs Total fixed costs - Total overhead and management costs. Simulations were ranked based on net income to evaluate relative differences as a result of management decisions and reproductive performance. It is difficult to evaluate absolute economic per-
TABLE 2. INFLATION-ADJUSTED NONFEED COSTS FOR A SPRING-CALVING COW HERD LOCATED IN A RANGE AREA

\begin{tabular}{|c|c|c|}
\hline Item & Unit & Price \\
\hline \multicolumn{3}{|l|}{ Cash costs } \\
\hline Veterinary and medicine ${ }^{\mathrm{a}}$ & $\$ /$ cow & 7.51 \\
\hline Marketing ${ }^{b}$ & $\$ / 100 \mathrm{~kg}$ & 4.47 \\
\hline Machinery and equipment ${ }^{a}$ & $\$ /$ cow & 9.61 \\
\hline Miscellaneous ${ }^{\mathrm{a}}$ & $\$ /$ cow & 3.53 \\
\hline \multicolumn{3}{|l|}{ Fixed costs } \\
\hline Death loss $c$ & $\$ /$ cow & 664 \\
\hline Building and equipment ${ }^{2}$ & $\$ /$ cow & 7.07 \\
\hline \multicolumn{3}{|l|}{ Other } \\
\hline Labor hours & $\mathrm{h} / \mathrm{cow}$ & 5.51 \\
\hline Labor rate & $\begin{array}{l}\$ / \mathbf{h} \\
5 \% \text { of items }\end{array}$ & 6.94 \\
\hline Overhead ${ }^{b}$ & charged interest & \\
\hline Operator management ${ }^{b}$ & $\$ /$ cow & 14.20 \\
\hline Interest rate & $\%$ & 12 \\
\hline
\end{tabular}

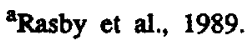

bJose, 1990.

${ }^{c}$ Cattle Fax, Denver, CO.

formance of any cow-calf operation using standardized guidelines because available resources and prices vary among operations within and across geographical areas. In most situations, prices for items purchased or sold are beyond the control of the producer, therefore, economic performance should be evaluated on a relative basis. To realistically assess the value of management decisions to an operation, all possible costs were considered, including those items for which there is no cash outlay.

\section{Results and Discussion}

Net income was compared within each postpartum interval $(48,65$, and $90 \mathrm{~d})$ for each length of breeding season, conception rate at first service, and time of breeding yearling heifers. Net income ranged from $\$ \$ 138,399$ to $\$ 203,237$. In this project, all costs and expenses were incorporated into the economic model, including those for which there is no cash outlay. Fixed costs for labor and interest on breeding animals were included in total other costs; however, these costs may not be incurred if all labor is provided by the operator and family and the cow herd is owned without debt. In addition, the period between 1980 and 1989 includes years when prices for feed inputs were high relative to prices received for livestock. Toward the end of the decade, feeder 
TABLE 3. EXPECTED INCOME AND COSTS FOR SHORT, MODERATE, AND LONG POSTPARTUM INTERVALS OF ANESTRUS ACROSS ALL SCENARIOS

\begin{tabular}{llllll}
\hline \hline $\begin{array}{l}\text { Postpartum interval } \\
\text { of anestrus, }\end{array}$ & Net income, & $\begin{array}{l}\text { Replacement } \\
\text { rate, }\end{array}$ & $\begin{array}{l}\text { Total feed } \\
\text { costs, }\end{array}$ & $\begin{array}{l}\text { Total other } \\
\text { costs, }\end{array}$ & $\begin{array}{l}\text { Total income, } \\
\text { d }\end{array}$ \\
\hline $\mathbf{\$}$ & $\$$ & $\%$ & $\$$ & $\$$ & $\mathbf{\$}$ \\
\hline 65 & $-155,991$ & 16.0 & 336,504 & 195,355 & 375,848 \\
90 & $-153,507$ & 17.4 & 326,902 & 196,420 & 369,815 \\
\hline
\end{tabular}

Total income less purchase of replacement livestock.

cattle prices began to climb and feed prices decreased; however, these changes in price trends were not enough to offset the high cost of inputs that occurred earlier.

Postpartum Interval of Anestrus. Net income was greatest with moderate postpartum intervals when results were averaged across all scenarios (Table 3). Total feed costs, total other costs, and total income were lower with moderate postpartum intervals relative to scenarios with short and long postpartum intervals.

Net income was influenced by length of breeding season within each postpartum interval. The 70-d breeding season resulted in the greatest net incomes when results were averaged across scenarios with short and moderate postpartum intervals (Tables 4 and 5). Conversely, the longer breeding season (120 d) was favored with long postpartum intervals. In addition, the magnitude of the difference in net income due to length of breeding season was much greater with long than with short postpartum intervals (data of Table 4 compared with data of Table 6).

Replacement rates, total feed costs, total other costs, and total income less the purchase of replacement livestock holding conception rate at first-service constant are shown in Tables 4, 5, and 6. Replacement rates were lowest with 120-d breeding seasons and increased with 70 - and $45-d$ breeding seasons. Total feed costs increased in a similar fashion because the herd consisted of more replacement heifers, bred heifers, and 2-yr-old cows, which were more costly to feed relative to weight of calf weaned than mature cows. Total other costs increased concurrently with replacement rates because more replacement heifers increased total cash costs and labor required.

The lowest net incomes resulted with 45-d breeding seasons combined with long postpartum intervals (Table 6). Replacement rates were greatest because a large number of cows were not in estrus or did not conceive during a short breeding season due to their long postpartum interval. Fewer calves were sold at weaning because a large number of heifer calves were retained for replacement purposes. However, total income was increased because a large number of cull cows were sold. The increased number of heifer calves retained combined with the high proportion of cows 2 or $3 \mathrm{yr}$ of age in the herd resulted in greater total feed costs relative to the weight of calves

TABLE 4. EXPECTED NET INCOME FOR SHORT POSTPARTUM INTERVALS OF ANESTRUS (48 DAYS) HOLDING CONCEPTION RATE AT FIRST-SERVICE CONSTANT

\begin{tabular}{lllllll}
\hline \hline $\begin{array}{l}\text { Time of } \\
\text { breeding } \\
\text { heifers }\end{array}$ & $\begin{array}{l}\text { Breeding } \\
\text { season, } \\
\text { d }\end{array}$ & $\begin{array}{l}\text { Net income, } \\
\mathbf{S}\end{array}$ & $\begin{array}{l}\text { Replacement } \\
\text { rate, } \\
\%\end{array}$ & $\begin{array}{l}\text { Total feed } \\
\text { costs, } \\
\$\end{array}$ & $\begin{array}{l}\text { Total other } \\
\text { costs, } \\
\mathbf{S}\end{array}$ & $\begin{array}{l}\text { Total income, } \\
\mathbf{S}^{\mathrm{b}}\end{array}$ \\
\hline HBW & 70 & $-154,221$ & 14.6 & 333,146 & 193,619 & 372,544 \\
HBE & 70 & $-154,510$ & 14.7 & 333,462 & 193,598 & 372,550 \\
HBE & 45 & $-155,864$ & 21.1 & 346,484 & 200,979 & 391,599 \\
HBW & 120 & $-155,960$ & 12.1 & 327,978 & 190,589 & 362,606 \\
HBE & 120 & $-157,609$ & 12.1 & 328,302 & 190,542 & 361,235 \\
HBW & 45 & $-157,783$ & 21.2 & 349,652 & 202,684 & 394,552 \\
\hline
\end{tabular}

${ }^{a} \mathrm{HBW}=$ heifers bred at same time as cows; $\mathrm{HBE}=$ heifers bred 3 wk before cows.

bTotal income less purchase of replacement livestock. 
TABLE 5. EXPECTED NET INCOME FOR MODERATE POSTPARTUM INTERVALS OF ANESTRUS (65 DAYS) HOLDING CONCEPTION RATE AT FIRST-SERVICE CONSTANT

\begin{tabular}{|c|c|c|c|c|c|c|}
\hline $\begin{array}{l}\text { Time of } \\
\text { breeding } \\
\text { beifers }^{\mathrm{a}}\end{array}$ & $\begin{array}{l}\text { Breeding } \\
\text { season, } \\
\text { d }\end{array}$ & $\begin{array}{l}\text { Net income, } \\
\$\end{array}$ & $\begin{array}{l}\text { Replacement } \\
\text { rate, } \\
\%\end{array}$ & $\begin{array}{l}\text { Total feed } \\
\text { costs, } \\
\$\end{array}$ & $\begin{array}{l}\text { Total other } \\
\text { costs, } \\
\$\end{array}$ & $\begin{array}{l}\text { Total income, } \\
\$^{b}\end{array}$ \\
\hline HBE & 70 & $-149,428$ & 15.4 & 322,225 & 193,936 & 366,733 \\
\hline HBE & 120 & $-149,920$ & 12.2 & 315,954 & 190,381 & 356,414 \\
\hline HBW & 120 & $-150,972$ & 12.4 & 315,898 & 190,491 & 355,418 \\
\hline $\mathrm{HBW}$ & 70 & $-152,322$ & 16.1 & 323,750 & 195,043 & 366,471 \\
\hline HBE & 45 & $-157,015$ & 23.2 & 338,180 & 202,699 & 383,863 \\
\hline HBW & 45 & $-161,383$ & 25.1 & 345,405 & 205,971 & 389,993 \\
\hline
\end{tabular}

${ }^{a} \mathrm{HBW}=$ heifers bred at same time as cows; HBE $=$ heifers bred 3 wk before cows.

botal income less purchase of replacement livestock.

at weaning. The cost of additional feed outweighed the greater income received from selling cull animals. Although not included in the model, more labor may be required for herds made up of a high percentage of cows 2 or $3 \mathrm{yr}$ of age due to the higher probability of dystocia at the first or second parturition.

The number of heavy calves at weaning was influenced by several factors when the postpartum interval was long (Figure 1). The number of heavy calves was lowest with short breeding seasons due to the large replacement rate. As a result of the large replacement rate, the average age of the herd was younger because it was composed of more cows 2 or 3 yr of age. Weaning weights of the calves were adjusted in the stochastic model (Azzam et al., 1990) to reflect the ages of the calves' dams. Calves weaned from cows 2 or $3 \mathrm{yr}$ of age weighed less at weaning than calves from mature cows. Therefore, more light and medium-weight calves were weaned in scenarios in which replacement rates were high. The number of heavy calves increased as length of the breeding season increased because the cow herd was composed of a greater number of mature cows, which weaned heavier calves. Length of breeding season did not influence the number of heavy calves at weaning in scenarios in which the postpartum interval was short or moderate. However, the number of light calves gradually increased as the breeding season was extended from 45 to 70 to $120 \mathrm{~d}$. With longer breeding seasons, more cows calved later, resulting in more younger and lighter calves at weaning. Differences in weaning weights were not simulated to reflect differences in the BCS of the cows because the potential for milk production was assumed to be the same for cows in all three levels of body condition.

Simulations of long postpartum intervals had the lowest feed requirements on a per-cow basis because the cows were assumed to be maintained in thin body condition (BCS $=3$ ) and required less feed to maintain their lighter BW. Likewise, when short postpartum intervals were simulated, cows were assumed to be

TABLE 6. EXPECTED NET INCOME FOR LONG POSTPARTUM INTERVALS OF ANESTRUS (90 DAYS) HOLDING CONCEPTION RATE AT FIRST-SERVICE CONSTANT

\begin{tabular}{|c|c|c|c|c|c|c|}
\hline $\begin{array}{l}\text { Time of } \\
\text { breeding } \\
\text { heifers }^{\mathbf{a}}\end{array}$ & $\begin{array}{l}\text { Breeding } \\
\text { season, } \\
\text { d }\end{array}$ & $\begin{array}{l}\text { Net income, } \\
\$\end{array}$ & $\begin{array}{l}\text { Replacement } \\
\text { rate, } \\
\%\end{array}$ & $\begin{array}{l}\text { Total feed } \\
\text { costs, } \\
\$\end{array}$ & $\begin{array}{l}\text { Total other } \\
\text { costs, } \\
\$\end{array}$ & $\begin{array}{l}\text { Tolal income, } \\
\$^{\mathrm{b}}\end{array}$ \\
\hline HBE & 120 & $-147,882$ & 13.1 & 299,991 & 190,888 & 342,998 \\
\hline HBW & 120 & $-157,421$ & 14.4 & 301,959 & 192,262 & 336,800 \\
\hline HBE & 70 & $-159,857$ & 23.1 & 319,941 & 201,127 & 361,210 \\
\hline HBW & 70 & $-174,779$ & 30.9 & 336,066 & 208,966 & 370,254 \\
\hline HBE & 45 & $-179,812$ & 40.6 & 357,513 & 218,776 & 396,477 \\
\hline HBW & 45 & $-192,427$ & 53.0 & 392,395 & 234,742 & 434,710 \\
\hline
\end{tabular}

${ }^{\mathrm{a}} \mathrm{HBW}=$ heifers bred at same time as cows; HBE = heifers bred 3 wk before cows.

botal income less purchase of replacement livestock. 


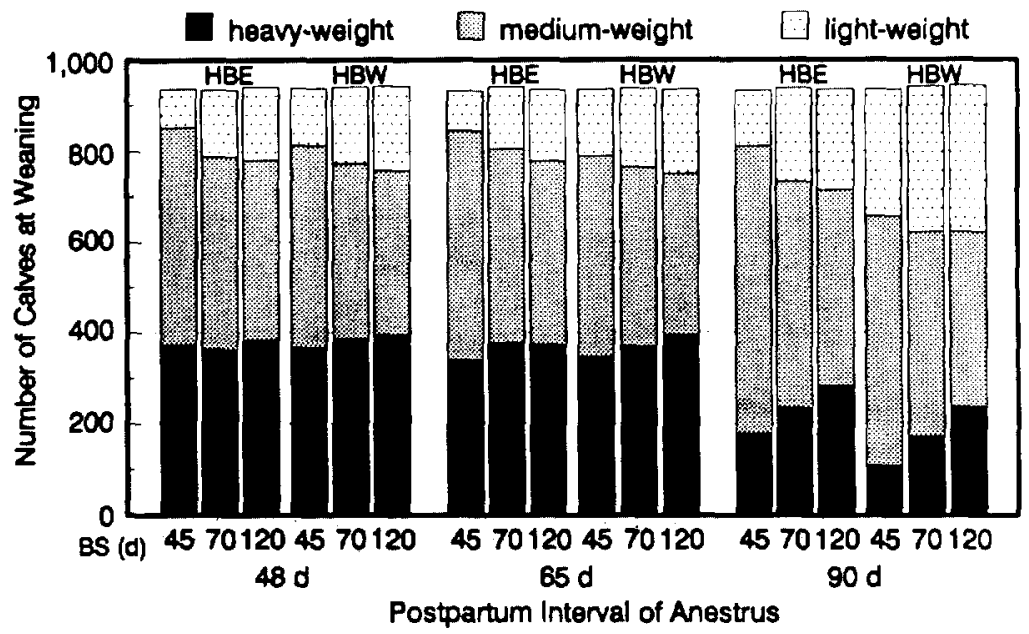

Figure 1. Distribution of number of light, medium, and heavy calves as influenced by postpartum interval of anestrus, length of breeding season, and initiation of breeding season for heifers. Conception rate at first service was equal to $70 \%$. $\mathrm{BS}=$ length of breeding season. $\mathrm{HBE}=$ heifers bred beginning 3 wk before the cows; $\mathrm{HBW}=$ heifers bred beginning at same time as cows.

in good condition $(B C S=7)$ and feed requirements were calculated based on the heavier BW of the fleshy cows. Regardless of average body condition of the cow herd, total feed costs accounted for 61 to $63 \%$ of the total herd costs. Taylor (1984) cited data from 110 beef cow herds in Missouri in which the proportion of total herd costs attributed to feed averaged $54 \%$ when interest on operating costs and breeding livestock was included. For operations with no interest costs, feed costs constituted 66 to $75 \%$ of the total annual cow cost. Unlike our simulation, variable and fixed costs associated with real estate were included in the data analyzed from Missouri.

Estimates for the amount of forage intake when cows grazed summer pasture were calculated to reflect management practices that would maintain cows in a predicted level of body condition. Thin cows were assumed to require less forage to maintain their BW (423 $\mathrm{kg})$ than cows in moderate condition $(477 \mathrm{~kg})$ or good condition $(532 \mathrm{~kg}$ ); however, cows in thin condition may still consume the same amount of forage as cows in moderate or good body condition. Therefore, the cows in thin condition were assumed to be grazing pastures that were managed with higher stocking rates than cows in the other two groups, and thus the feed intake of thin cows would be limited.
The long-term effects of high stocking rates on quality of forage are not included in the economic model.

Conception Rate at First Service. Conception rate at first service was treated similarly for each postpartum interval and level of body condition. Previous studies have reported that inadequate dietary energy during the postpartum period reduces (Wiltbank et al., 1964; Dunn et al., 1969) or tends to reduce (Wiltbank et al., 1962; Somerville et al., 1979; Richards et al., 1986) conception rates at first service. In this study, feed requirements were calculated to maintain BW for each level of body condition considered and to support lactation for cows of this crossbred type. Net income increased as conception rate at first service increased, regardless of postpartum interval (Figure 2). The greatest net income resulted with $80 \%$ conception rates at first service; likewise, the poorest net incomes resulted with $60 \%$ conception rates at first service within any length of breeding season. Conception rate at first service influenced the distribution of conception dates within the cow herd, which influenced pregnancy rate and mean calving date. Higher conception rates at first service resulted in greater pregnancy rates, and thus replacement rates were lower. Fewer heifer calves were retained at weaning as a 
result; therefore, total feed costs were lower. Total income was greater with $60 \%$ conception rates at first service because more nonpregnant cull cows were sold.

More calves were bom during the first $21 \mathrm{~d}$ of the calving season as conception rate at first service increased. The greatest number of heavy calves weaned occurred with $80 \%$ conception rates at first service and the greatest number of light calves weaned occurred with $60 \%$ conception rates at first service (not shown).
Length of Breeding Season. The optimum length of breeding season depended on the postpartum interval. Moderate breeding seasons (70-d) were most profitable with short or moderate postpartum intervals, which is in agreement with the results of Deutscher et al. (1991). They reported a 5-yr study conducted in the Nebraska Sandhills that evaluated the effects of three breeding programs $(30,45$, and $70 \mathrm{~d})$ on calf performance and reproductive performance of the cow. Weight of calf weaned per cow was highest with $70-d$

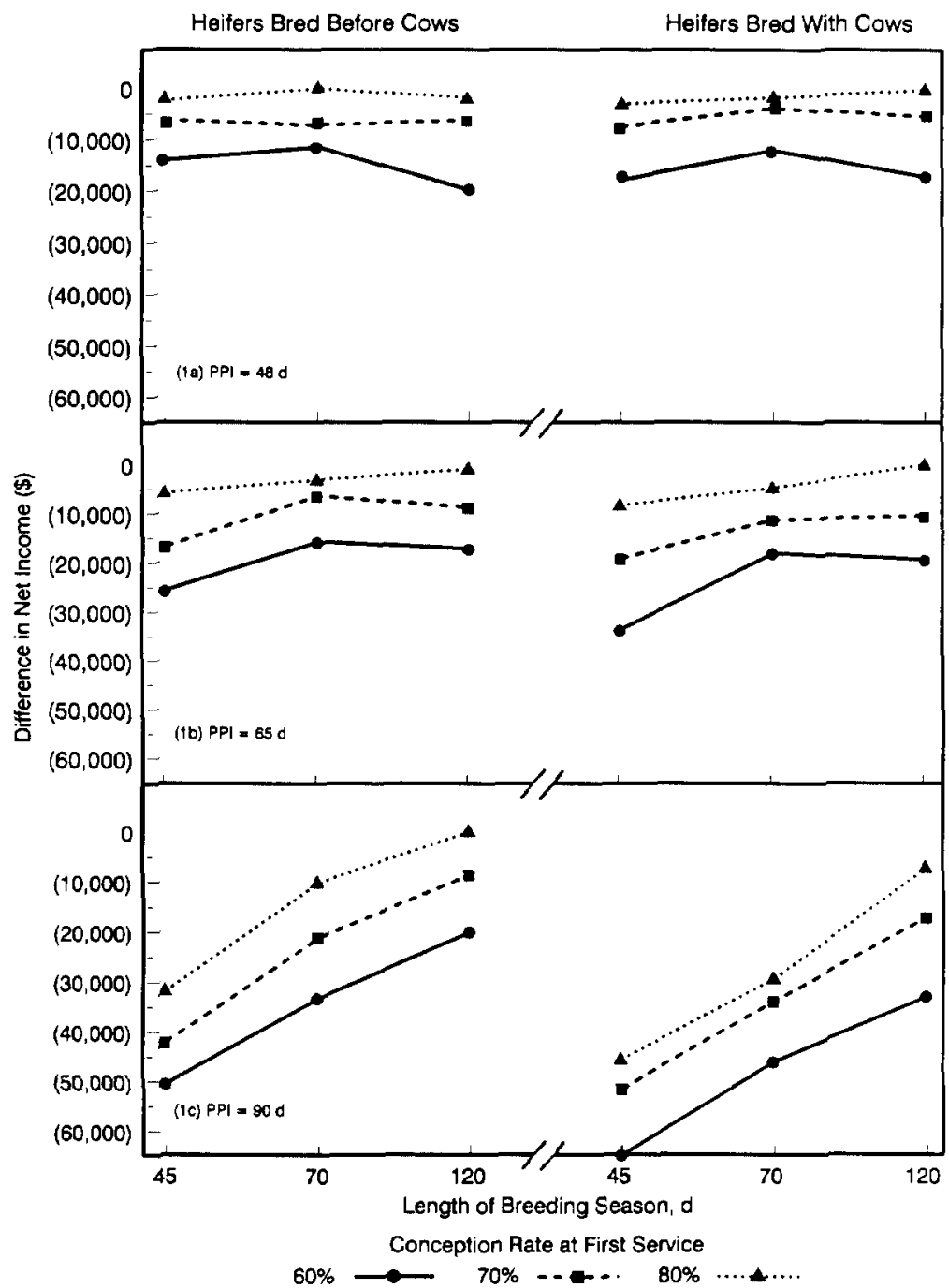

Figure 2. Difference in expected net income when postpartum intervals of short (1a), moderate (1b), and long (1c) duration were simulated with three lengths of breeding season and three conception rates at first service depending on whether initiation of the breeding season for heifers occurred 3 wk before that for the cows or at the same time as that for the cows. In each graph, the simulation with the greatest net income was assigned a value equal to 0 . All other simulations are presented as the amount the net income differs from the simulation with the greatest net income. 
TABLE 7, EXPECTED INCOME AND COSTS FOR INITIATING THE BREEDING SEASON FOR HEIFERS EITHER 3 WEEKS BEFORE (HBE) OR AT THE SAME TIME AS (HBW) THAT FOR THE COW HERD ACROSS ALL SCENARIOS

\begin{tabular}{llllll}
\hline \hline $\begin{array}{l}\text { Time of } \\
\text { breeding } \\
\text { heifers }\end{array}$ & $\begin{array}{l}\text { Net income, } \\
\$\end{array}$ & $\begin{array}{l}\text { Replacement } \\
\text { rate, } \\
\%\end{array}$ & $\begin{array}{l}\text { Total feed } \\
\text { costs, } \\
\mathbf{S}\end{array}$ & $\begin{array}{l}\text { Total other } \\
\text { costs, } \\
\mathbf{S}\end{array}$ & $\begin{array}{l}\text { Total income, } \\
\mathbf{S}^{\mathrm{a}}\end{array}$ \\
\hline HBE & $-156,878$ & 19.5 & 329,117 & 198,103 & 370,342 \\
HBW & $-161,919$ & 22.2 & 336,250 & 201,596 & 375,928 \\
\hline
\end{tabular}

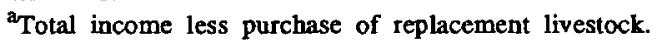

breeding seasons due to higher pregnancy rates and weaning rates compared with 30 - and 45-d breeding seasons.

After review of several studies, Dzuik and Bellows (1983) concluded that the length of the breeding season should not exceed $60 \mathrm{~d}$ to optimize the efficiency of the beef cow herd. However, intensive management practices, adequate feed levels, and careful observations during short calving seasons are necessary to achieve a high level of production. In contrast, research by Pritchard (1987) and Fiske (1987) indicated that the optimal length of the breeding season depended on conception rate at first service with postpartum intervals of moderate length. When conception rates at first service were high ( 70 to $80 \%$ ), there was little difference in net income due to length of breeding season. When conception rates at first service were low (50 to $60 \%$ ), longer breeding seasons $(120 \mathrm{~d})$ were more profitable because a greater number of cows became pregnant and subsequently weaned calves. In the present study, long breeding seasons resulted in the greatest net income with long postpartum intervals because pregnancy rates were greater than when 45- and 70- $d$ breeding seasons were used. A larger proportion of young, light calves at weaning achieved through increased pregnancy rates was economically better than weaning fewer calves.

The amount of labor required per cow was assumed to be constant in all scenarios regardless of length of breeding season. Requirements for labor when short breeding seasons were used may overestimate the actual amount of labor required. With long breeding seasons, the labor required may underestimate the actual labor needed. In addition, breeding heifers to begin calving 3 wk ahead of the cow herd lengthens the calving season by 3 wk and extends the length of time that additional labor is required. Short calving seasons concentrate the amount of labor required into a shorter period of time; however, more employees may be needed during the first 3 wk of the calving season when the majority of cows calve.

If cow-calf production is not the main ranch enterprise, then short breeding seasons may be necessary to allow labor to be available when other enterprises require labor inputs. Long breeding seasons extend the requirement for labor, especially when heifers are bred early. If cow-calf production is not the main enterprise on the ranch and long breeding seasons are used, labor may be transferred to another enterprise at some time before the end of the calving season. Productivity of the cow herd may decline as a result if gestating cows are not closely observed near the end of the calving season. Composition of the cow herd may also influence labor requirements. Management decisions and levels of reproductive performance that result in a larger number of replacement heifers may require additional labor during calving because the probability of dystocia is greater at first parturition.

Time of Breeding Yearling Heifers. Net income was greatest due to lower replacement rates when the breeding season for heifers was initiated 3 wk ahead of that for the cows rather than concurrently with that for the cows (Table 7 ). The lactating cow at 2 yr of age has more time to return to estrus before the start of her second breeding season if she is bred to calve 3 wk ahead of the mature cow herd. Therefore, in this simulation, more 2-yr-old cows were in estrus and could conceive during the breeding season, which resulted in increased pregnancy rates compared with situations in which heifers were bred beginning at the same time as the cows.

Breeding heifers 3 wk ahead of the cows resulted in slightly greater feed costs for bred heifers on a per cow basis due to the additional 3 wk of receiving the lactation diet before June 
1 when all cows were moved to pasture. However, total feed costs were lower because fewer replacement heifers were retained than when heifers were bred beginning at the same time as the cows. Breeding yearling heifers early provided the greatest economic benefit with long postpartum intervals. When short postpartum intervals were simulated, there was little economic advantage to breeding yearling heifers before the cows regardless of length of breeding season because cows that were 2 yr of age and in fleshy body condition returned to estrus within $60 \mathrm{~d}$ after parturition.
Average age of cows in the herd was directly related to the replacement rate. Average age was greater in scenarios in which replacement rates were low because more cows became pregnant before the end of the breeding season and were retained in the cow herd. When more older cows were in the herd, more cows were culled for physical reasons.

General Discussion. Simulation modeling is an ongoing process that can help researchers identify areas in which further research is needed. Areas that have been identified throughout this project include 1) actual labor

\section{Interaction of Management and Reproductive Performance on Net Income}

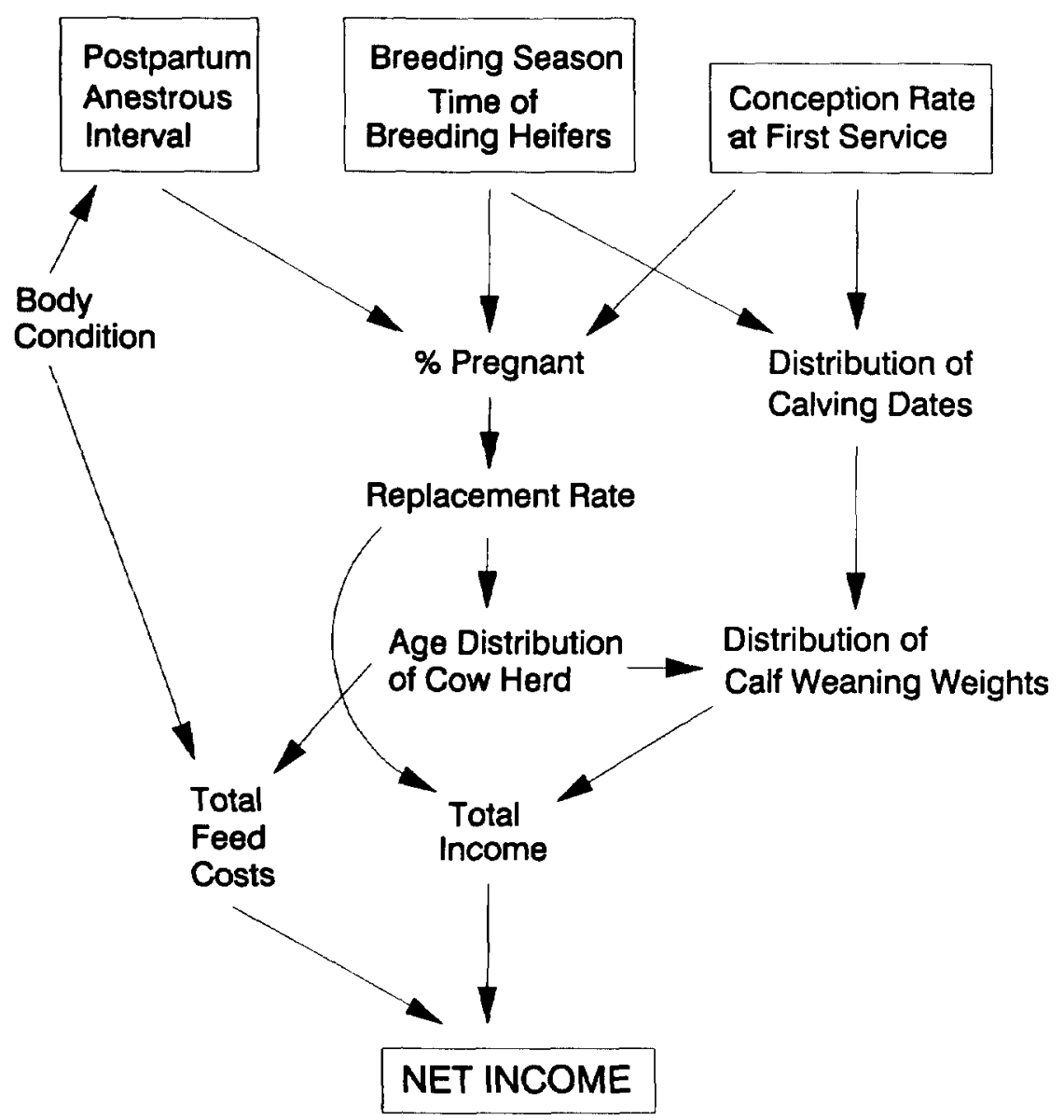

Figure 3. Flow diagram depicting how management decisions and reproductive performance influence production of the cow herd. 
required during the calving season as influenced by length of calving season, average age of the cow herd, and prevalence of dystocia, 2) forage intake of cows in various levels of body condition and effects on milk production and effects of overgrazing/undergrazing on pasture quality during future grazing seasons, and 3 ) calf survival as influenced by age of dam, body condition of dam, birth date, and weather conditions.

Figure 3 is a conceptual model of how management decisions and reproductive performance influence the biological production of the cow herd, which ultimately influences net income of the enterprise. The biological potential of the cow is influenced by how she is managed. For example, the quantity and(or) quality of harvested feed and forage available is reflected in the body condition of the cow. Body condition of the cow then influences when the cow will return to estrus after parturition. Cows in good body condition are expected to return to estrus earlier than cows in thin body condition. Consequently, a large percentage of cows in good body condition would be expected to conceive during a short breeding season ( $45 \mathrm{~d}$ ). Cows in thin body condition, as a result of management decisions or unavoidable circumstances such as weather conditions or poor feed availability and(or) quality, cannot be expected to perform as well when given the constraints of a short breeding season. This was apparent when long postpartum intervals (90 d) were simulated with short breeding seasons ( $45 \mathrm{~d}$ ).

Pregnancy rates are also influenced by conception rate at first service, which dictates when the cow conceives and calves. If conception rate at first service is low during the breeding season, then more calves will be born late, pregnancy rates will decrease, and more light calves will be weaned; thus, total income will decrease. Therefore, producers should use management decision that will optimize the performance of the cow herd (pregnancy rate, distribution of weaning weights) given the condition of the cows.

\section{Impllcations}

Net income was greatest with 70-d breeding seasons when postpartum intervals were short or moderate in length assuming that cows were in good to moderate body condition. However, net income was only slightly lower when breeding seasons were extended to $120 \mathrm{~d}$. If short breeding seasons are used and a large number of cows are removed from the herd because they do not become pregnant, then the breeding season may need to be extended to increase the pregnancy rate and increase net income. Results from this study indicate that selling a light calf that was born late is more profitable than selling a nonpregnant cow and replacing her with a heifer calf. Above all, management practices that maintain a greater percentage of mature cows in the herd should optimize both reproductive and economic efficiencies because more calves that are heavier are produced relative to the quantity of feed necessary for maintenance and lactation.

\section{Literature Clted}

Azzam, S, M., J. E. Kinder and M. K. Nielsen. 1990. Modelling reproductive management systems for beef cattle. Agric. Systems 34:103.

Azzam, S. M., L. A. Werth, J. E. Kinder and M. K. Nielsen. 1991. Distribution of time to first postpartum estrus in beef cattle. J. Anim. Sci. 69:2563.

Bellows, R. A., R. E. Short and R. B. Staigmiller. 1979. Research areas in beef cattle reproduction. In: $H$. Hawk (Ed.) Beltsville Symp. Agric. Res. 3, Animal Reproduction. pp 3-18. Allanheld, Osmun and Co. Publishers, New York.

Business Conditions Digest. 1989. Vol. 29, no. 11. United States Department of Commerce, Washington, DC.

Cornhusker Economics. 1980 to 1989. Dept. of Agric. Econ., Univ. of Nebraska, Lincoln.

Deutscher, G. H., J. A. Stotts, and M. K. Nielsen. 1991. Effects of breeding season length and calving season on range beef cow productivity. J. Anim. Sci. 69:3453.

Dunn, T. G., J. E. Ingalls, D. R. Zimmerman and J. N. Wiltbank. 1969. Reproductive performance of 2-year-old Hereford and Angus heifers as influenced by pre- and post-calving energy intake. J. Anim. Sci. 29:719.

Dziuk, P. J. and R. A. Bellows. 1983. Management of reproduction of beef cattle, sheep and pigs. J. Anim. Sci. 57(Suppl. 2):355.

Fiske, D. A. 1987. Economic consequences of alternative reproductive management practices for beef cow herds in Nebraska. M.S. Thesis. Univ. of Nebraska, Lincoln.

Houghton, P. L., R. P. Lemenager, L. A. Horstman, K. S. Hendrix and G. E. Moss. 1990. Effects of body composition, pre- and postpartum energy level and early weaning on reproductive performance of beef cows and preweaning calf gain. J. Anim. Sci. 68:1438.

Jose, H. D. (Ed.). 1990. Estimated Crop and Livestock Production Costs; 1990. Coop. Ext. Serv. Publ. No. 161. Univ. of Nebraska, Lincoln.

Momont, P. A. and R. J. Pruitt. 1989. Effects of body condition on reproductive performance of range beef cows. J. Anim. Sci. 67(Suppl. 2):89 (Abstr.).

Nebraska Dept. of Agric. 1989. 1988 Nebraska Agricultural Statistics. October.

NRC. 1984. Nutrient Requirements of Beef Cattle (6th Ed.). National Academy Press, Washington, DC. 
Pritchard, S. M. 1987. Simulated economic efficiency of beef production for different breeding seasons. M.S. Thesis. Univ. of Nebraska, Lincoln.

Rasby R. J., W. M. Frasier, G. H. Deutscher, I. G. Rush, T. L. Mader, J. A. Gosey and D. B. Hudson. 1989. Nebraska Integrated Reproductive Management Demonstration Project 1984-1988. Coop. Ext. Serv. Publ. No. AnSci 89-1. Univ. of Nebraska, Lincoln.

Richards, M. W., J. C. Spitzer and M. B. Warner. 1986. Effect of varying levels of postpartum nutrition and body condition at calving on subsequent reproductive performance in beef cattle. J. Anim. Sci. 62:300.

Short, R. E., R. A. Bellows, R. B. Staigmiller, J. G. Berardinelli and E. E. Custer. 1990. Physiological mechanisms controlling anestrus and infertility in postpartum beef cattle. J. Anim. Sci. 68:799.

Somerville, S. H., B. G. Lowman and D. W. Deas. 1979. The effect of plane of nutrition during lactation on the reproductive performance of beef cows. Vet. Res. 104: 95.

Taylor, R. E. 1984. Beef Production and the Beef Industry: A Beef Producer's Perspective. Burgess Publishing Co., Minneapolis, MN.
Wellman, A. C. and L. H. Lutgen. 1990. Crop and Livestock Prices for Nebraska Producers. Coop. Ext. Serv. Publ. No. EC 90-883. Univ. of Nebraska, Lincoin.

Werth, L. A., S. M. Pritchard, S. M. Azzam, D. A. Fiske, G. H. Pfeiffer, M. K. Nielsen and J. E. Kinder. 1991. Evaluating net income from different durations of breeding seasons in beef production using a deterministic simulation model. Agricultural Systems (In press).

Wiltbank, J. N., W. W. Rowden, J. E. Ingalls, K. E. Gregory and R. M. Koch. 1962. Effect of energy level on reproductive phenomena of mature Hereford cows. J. Anim. Sci. 21:219.

Wiltbank, J. N., W. W. Rowden, J. E. Ingalls and D. R. Zimmerman. 1964. Influence of post-partum energy level on reproductive performance of Hereford cows restricted in energy intake prior to calving. J. Anim. Sci. 23:1049.

Zalesky, D. D., M. L. Day, M. Garcia-Winder, K. Imakawa, R. J. Kittok, M. J. D'Occhio and J. E. Kinder. 1984. Influence of exposure to bulls on resumption of estrous cycles following parturition in beef cows. J. Anim. Sci. 59:1135. 